\author{
Translation Analysis of Address Terms in the Novel Entitled \\ Percy Jackson \& The Olympians: The Lightning Thief
}

\author{
Marita Dwi Isdhianty \\ Universitas Sebelas Maret
}

\begin{abstract}
Author Note
Author is a student of English Department, Faculty of Cultural Sciences, Universitas Sebelas Maret, Jalan Ir. Sutami 36A, Surakarta, Indonesia (e-mail: maritadwi18@gmail.com)
\end{abstract}




\begin{abstract}
The aims of this study are to identify the type of address terms found in an English novel entitled Percy Jackson \& The Olympians: The lightning thief, to identify translation techniques used by the Indonesian translator to translate the address terms, and to describe translation quality of address terms in the novel entitled Percy Jackson \& The Olympians: The lightning thief.

It is a qualitative study in which the data are words and phrases accommodating address terms in English as source text and it's translation as target text. The data were collected through content analysis and focus group discussion. The collected data were then analyzed based on data analysis model which is proposed by Spradley.
\end{abstract}

There are 15 types of address terms found in the novel. Generic first name is the most dominant type of address terms found in the novel. The use of this term shows that the relation between the addresser and the addressee is rather close. The result shows that the translator uses single technique and combination of 2 techniques to translate the address terms. The translator uses established equivalent to translate some types of address terms in the novel, such as title, generic first name, mockery name, etc. She also uses pure borrowing to translate first name, diminutive name, last name, etc. The accuracy and the acceptability of the translation of the address terms are high. The high level of accuracy and acceptability in this research is the result of the application of established equivalent technique and pure borrowing. The high degree of accuracy and acceptability of the translation of address terms in this novel reflects attentiveness and carefulness of the translator in making decisions about the choices of translation techniques, which are required in cases of translating address forms as translating this type of expression can be complicated due to the strong cultural influence of encompassing source language and target language

Keywords: translation technique, translation quality, address terms, novel, Percy Jackson. 


\section{Translation Analysis of Address Terms in the Novel Entitled Percy Jackson \& The Olympians: The Lightning Thief}

Communication is very important in humans' life. As a part of society, human interaction cannot be avoided. In communication, the communicators need to address one another to gain attention. They use address terms to gain attention of the other communicators. According to Crystal (2008), address terms are "the manner of referring to someone in direct linguistic interaction." Yule (1996) also stated that address terms are words and phrases used to address someone else in written form or spoken form. Moreover, address terms are also used to show certain relations between people, or to show the difference in identity, position and social status. Address terms in written form are usually found in literary works such as novels, short stories, movies, comics, etc.

As a part of literary works, novel can be defined as a long-invented prose narrative that is created from imagination, not as a fact, though it may be based on true stories or true situations. A novel deals with humans' experience through a connected sequence of events involving a group of people in certain setting. Through a novel, someone can learn more about humans' life, including how humans communicate with each other and how humans address each other.

A novel entitled Percy Jackson \& The Olympians: The lightning thief is one of literary works containing address terms in it. The genre of this novel is fantasy. The original version of this novel is in English. The author of this novel is Rick Riordan. It tells a story about the journey of a teenage boy named Percy Jackson, who recently finds out that he is a demigod, searching the real thief of Zeus's lightning bolt to prove that he is not the one steling it.

This novel was first published in 2005. Through the years, this novel also got several awards such as New York Times bestseller, the winner of Mark Twain Award in 2008, A Best Book of 2005 by Child Magazine, ALA Notable Book for 2005, etc. The popularity of this novel made Noura Books Publisher (PT Mirzan Publika) translate this novel into Indonesian. It was translated into Indonesian by Femmy Syahrani. Various address terms were found in this novel. 
Several unique address terms that are found in the novel lead to the research of the translation of address terms in Percy Jackson \& The Olympians: The Lightning Thief novel. The novel was chosen as the source of data because various address terms are found in it. It would be challenging to see how the translator of this novel translates address terms into Indonesian.

Translating address terms can be complicated because address terms are highly influenced by culture. Translation of address terms has been a focus study by several researchers. Yang (2010) made a research about the translation of English and Chinese address terms from the aspect of cultural background. This research is based on humans' cross-cultural communications in the real life. From the research, Yang found that in translating English-Chinese address terms, translators used 4 methods which are applied based on different situations, namely, literal translation, translating flexibly, specification or generalization, and domestication and foreignization.

Different from Yang who focused on the methods used in translating English-Chinese address terms, Widyastuti (2015) on her research focused on the pragmatic equivalence in translating EnglishIndonesian address terms in the subtitle of SpongeBob Squarepants Movie: Sponge Out of Water (2014). From the research, she found out that although English-Indonesian address terms used in the movie have similar equivalence tendency, the meaning and the impact of the address terms can be different.

Lotfollahi and Dabbaghi (2012) also studied strategies and procedures used by Persian translators to translate address terms from English to Persian. They found out that there are several differences between English address terms and Persian address terms. To fill this gap, translators use various strategies such as deletion, addition, cultural equivalent, and transcription. From this research, they found that the use of literal translation would obliterate the meaning of address term translated from English to Persian.

Fauliyah (2012) also investigated the translation of Indonesian address terms to English in a movie entitled Ketika Cinta Bertasbih II to know the strategies used by the translator to deliver the function of address terms from the source language to the target language. She found that the address term used in this movie belongs to pronoun. Meanwhile, the strategy that is usually used to translate address terms is 
"using more general terms". Fauliyah also found that the translator tends to accommodate the target reader more than maintaining the culture of Indonesian address terms.

Address terms in one culture can be different from address terms in another. A translator has to use the correct translation techniques to translate address terms to produce a high-quality translation. Different from the previous researches, this research focuses on translation techniques used by the translator to translate address terms and how the translation techniques used by the translator influence the quality of the translation. 


\section{Method}

This research applies descriptive qualitative method. The data that are analyzed in this research are the address terms in the novel entitled Percy Jackson \& The Olympians: The Lightning Thief. The data were obtained by analyzing the source text and target text. The other data were obtained by comparing the address terms both from the source text and from the target text. By comparing them, translation techniques that are used by the translator to translate the address terms were identified. Besides, the collected data here are in the forms of information. This information was obtained from the raters used for assessing quality of translation of address terms in the novel. The data sources consist of (1) the novel entitled Percy Jackson \& The Olympians: The Lightning Thief and its translation and (2) raters. The validation and the translation quality assessment were carried out by doing focus group discussion. 


\section{Result}

\section{Types of Address Terms}

The address terms in the novel entitled "Percy Jackson \& The Olympus: The Lighting Thief" are obtained from the conversations between the characters in the novel. The address terms are identified based on the contexts of situation of the conversations and the relations between the characters invoved within. Address terms itself is a word or phrase which is used to address someone in writing context or in speech context. Moreover, the address terms are also used to get someone's attention in a conversation. The use of the address terms is based on several factors, such as age, gender, social class, context of situation and so on.

There are 170 address terms found in the novel which can be classified into 15 types of address terms. The types of address terms found are based on Wardhaugh's theory about address terms, but some of the types found are still unfamiliar. The types of address terms included in this study are title, first name, generic first name, diminutive first name, last name, complete name, title plus last name, mockery name, pet name, descriptive name, kinship term, expectation name, single name, title plus single name, and title plus contraction. The distribution of the types of address terms found can be seen in the following table.

Table 1 Types of Address Terms

\begin{tabular}{llll}
\hline No. & Types of Address Terms & Total Data & Percentage (\%) \\
\hline 1. & Title & 20 & $11.8 \%$ \\
2. & First Name & 18 & $10.5 \%$ \\
3. & Generic First Name & 30 & $17.7 \%$ \\
4. & Diminutive First Name & 15 & $8.8 \%$ \\
5. & Last Name & 1 & $0.5 \%$ \\
6. & Complete Name & 8 & $4.7 \%$ \\
7. & Title plus Last Name & 5 & $3 \%$ \\
8. & Mockery Name & 23 & $13.5 \%$ \\
9. & Pet Name & 12 & $7.1 \%$
\end{tabular}


10. Descriptive Name

11. Kinship Term

12. Expectation Name

13. Single Name

14. Title plus Single Name

15. Title plus contraction

Total
15

8

3

6

3

3

170
$8.8 \%$

$4.7 \%$

$1.8 \%$

$3.5 \%$

$1.8 \%$

$1.8 \%$

$100 \%$

Table 1 shows that generic first name is the most dominant type of address terms found in the novel. There are 30 data found to be included in generic first name type. This type of address is usually used to address others who are friendly or familiar with the addresser. It can be used to address a fellow, friend colleague, partner or someone with whom something is shared. Despite having a similar term, generic first name and first name are different. Generic first name uses terms like buddy, mate, man, etc. to address the addressee while first name type uses the addressee's real first name (Wardhaugh, 1988). The use of generic first name shows that the relation between the addresser and the addressee is rather close. Generic first name is also often used to show friendliness to the addressee. For example,

\section{Example 1}

I looked over at Grover to say something about this and saw that the blood had drained from his face. His nose was twitching. "Grover?" I said. "Hey, man-"

The example 1, the address term 'man' appears. The address term is used by Percy to address Grover. The word 'man' is a friendly term that is usually reserved for close male friends. Thus, it matches perfectly with the definition of generic first name. A large number of this address term appear in the analysis because the majority of the characters in the novel are teenagers and they are friends with each other. The other examples of this type of address in the novel are boy, mate, etc.

Table 1 also shows that 23 data of the whole data are included in the mockery name category. Mockery name is a name that is created with the purpose of mocking a person (Cambridge, 2008). The use of this term of address indicates that the relation between the addresser and the addressee is bad. This 
type of address appears in the novel, because the main character of this novel, Percy Jackson, tends to make other characters mad or feeling irritated toward him while he is having conversation with them. Thus, other characters use mockery name to address the main character. For example,

\section{Example 2}

"Your report card came, brain boy!" he shouted after me. "I wouldn't act so snooty!"

Example 2 shows that the address term 'brain boy' appears. Gabe, Percy's step-father addresses Percy using the term 'brain boy'. The purpose of using the address terms 'brain boy' is to mock and annoy Percy, because Percy is an average student. He is not in the position to be called smart. Thus, Gabe addresses Percy by mockery name. Some of mockery names appearing in this novel are slightly unusual. It is because the novel itself tells a story about the adventure of Percy Jackson, Poseidon's son which is the Greek Gods of the sea. This causes some of the mockery names to be related to the Greek God and Goddess mythology.

There are 20 data which are included in the title address term. Title is a prefix (honorific) or suffix (post-nominal) added to a person's name to signify veneration, official position, or a professional or academic qualification (Cambridge, 2008). In the novel, the use of title as an address term is for addressing teachers, camp's director, Gods, Goddesses, etc. The examples of this type of address are sir, lord, ma'am, etc. Besides, 18 data are categorized as first name. First name is a name that is given to a person when the person is born and it comes before your family name (Cambridge, 2008). It can be rude to call others by their first names if they are much older or have more power than the addresser. The addresser has to be friendly or familiar enough with others to call them by their first names. The examples of this type of address in the novel are Annabeth, Perseus, Grover, Clarisse, etc. Table 1 shows that 15 data are categorized as diminutive first name. Diminutive first name is a name to address someone by a short part of the addressee's first name (Wardhaugh, 1988). Diminutive can also be formed by adding suffix to the original name or the name's short form. In English, the -y/-ie suffix is very common. The examples of this type of address in the novel are Percy and Gabe. There is only 1 datum which is categorized as last name. Last name is a family name that is used in formal situations or with 
people you do not know well. The use of this address term sometimes shows that the addresser has higher position than the addressee (Wardhaugh, 1988). The example of this type of address in the novel is Jackson, Jackson is Percy's last name. The table also shows that 8 data are included in complete name category. Complete name is a first name, middle name (if they have), and last name of people. Complete name is also known as full name (Cambridge, 2008). The example of this type of address in the novel is Percy Jackson. From the table 1, it can be seen that 5 data are categorized into title plus last name. Title plus last name is a name consisting of a person's title and last name (Wardhaugh, 1988). The title here refers to a person social rank, qualifications, position in an organization, sex, etc. There are 12 data that are included in pet name. Pet name is an informal name given by one's family or friends. This term of address shows that the addresser has close relationship with the addressee. The purpose of using pet name is to show intimacy (Wardhaugh, 1988). The examples of this type of address in the novel are dear, honey, and sweetheart. Besides, the table also shows that 15 data are included in descriptive name. Descriptive name is a name that is used to describe a person or a group of people based on their appearance. The examples of this type of address in the novel are blue team and goat boy. The table indicates that 8 data are categorized into kinship term. Kinship term is a name that is used to address family members. This type of address term indicates the relation between family members (Wardhaugh, 1988). There are 3 data in the table above which are included in expectation name. The example of this type of address is hero. In addition, 6 data are included in single name. Single name is a name addressed to someone who only has single name without last name. It can be birth name, stage name, pen name, etc (Cambridge, 2008). The examples of this type of address are Chiron, Zeus, Poseidon, Hades, etc. Greek mythology characters usually only have single name. The table also shows 3 data of title plus single name. Title plus single name is a combination of title and single name. This name is used to address someone who has single name only and has higher position than the addresser. This address term shows the respect of the addresser toward the addressee (Wardhaugh, 1988). This type of address is usually used in the novel to address Gods and Goddesses of Olympus. Lastly, 3 data of title plus contraction are also found in the novel. Title plus contraction is an address term in the form of combination between title 
and name contraction. Name contraction itself is a shortened form of someone name. This type of address shows the addresser's respect for the addressee. This type of address is used to address Dionysus, A God.

\section{Techniques which are applied by the translator to translate the address term}

The analysis of the translation techniques shows that there are 14 techniques which are used by the translator to translate 170 address term found in the novel. They are divided in 2 big groups; single technique and combination of 2 techniques. The single technique consists of 9 types of translation techniques and the combination of 2 techniques consists of 5 types of translation techniques.

Table 2 Translation Techniques

\begin{tabular}{|c|c|c|c|}
\hline No. & $\begin{array}{l}\text { The Amount of Techniques } \\
\text { Combination }\end{array}$ & Total Data & Percentage $(\%)$ \\
\hline \multirow[t]{10}{*}{1.} & Single Technique (156) & & \\
\hline & a. Deletion & 5 & $3 \%$ \\
\hline & b. Discursive Creation & 7 & $4.1 \%$ \\
\hline & c. Established Equivalent & 65 & $38.2 \%$ \\
\hline & d. Explicitation & 2 & $1.1 \%$ \\
\hline & e. Generalization & 9 & $5.3 \%$ \\
\hline & f. Literal & 5 & $3 \%$ \\
\hline & g. Modulation & 12 & $7.1 \%$ \\
\hline & h. Particularization & 1 & 0.6 \\
\hline & i. Pure Borrowing & 50 & $29.4 \%$ \\
\hline \multirow[t]{7}{*}{2.} & Combination of 2 Techniques (14) & & \\
\hline & a. Addition + Pure Borrowing & 1 & $0.6 \%$ \\
\hline & $\begin{array}{l}\text { b. Established Equivalent } \\
\text { Established Equivalent }\end{array}$ & 3 & $1.8 \%$ \\
\hline & $\begin{array}{l}\text { c. Established Equivalent }+ \text { Pure } \\
\text { Borrowing }\end{array}$ & 7 & $4.1 \%$ \\
\hline & d. Literal + Established Equivalent & 1 & $0.6 \%$ \\
\hline & e. Reduction + Pure Borrowing & 2 & $1.1 \%$ \\
\hline & TOTAL & 170 & $100 \%$ \\
\hline
\end{tabular}


The translator uses 9 single techniques and 5 combinations of two techniques to translate the address terms in the novel. The techniques uses by the translator are based on 18 techniques proposed by Molina \& Albir (2002). In this research, most of the address terms are translated correctly by using the appropriate The large number of this address term appears technique. However, some of the address terms are also translated using less proper techniques. The use of proper translation techniques does not cause the change in the meaning contained in the address terms. On the other hand, the use of improper translation techniques can cause the meaning in the address terms not to be delivered successfully. In translating the address terms the translator needs to be careful in order not to distort the address terms. According to the analysis of the techniques, the translator uses 11 different techniques to translate the address terms in the novel entitled "Percy Jackson \& The Olympians: The lightning thief". The techniques are not used in the same frequency. There are two classification, which are single techniques and combination of 2 techniques.

The 11 techniques which are used by the translator are deletion, discursive creation, established equivalent, explicitation, generalization, literal, modulation, particularization, pure borrowing, addition, and reduction. Established equivalent is often applied by the translator to translate the address terms, which makes established equivalent have the highest frequency of technique used by the translator. On the other side, particularization and addition are the techniques which are rarely applied by the translator to translate the address terms in this research. There are 65 data which are included in established equivalent. The translator mostly uses this type of technique to maintain the meaning of the address term in the source text. The translator uses established equivalent to translate types of address terms such as title, generic first name, mockery name, and pet name. The translator also uses pure borrowing technique frequently. This technique is the second most applied technique by the translator. Pure borrowing is applied in translating types of address terms such as first name, last name, diminutive first name, complete name, etc. This technique is usually used to translate address terms in the form of proper name. 


\section{The impact of the application of translation techniques by the translator toward the level of accuracy and acceptability}

Based on the analysis on the quality of the translation of address term is the novel entitled "Percy Jackson \& The Olympians: The lightning thief', it can be concluded that the quality of the translation of the address terms is high. The translation techniques that are applied correctly by the translator contribute to the high level of accuracy and acceptability of the address terms.

\section{a. The level of accuracy}

According to Nababan, Nuraeni, and Sumardiano (2012), accuracy is the level of equivalence between the message of the source text and the message of the translation. This research uses three instruments to measure the level of accuracy of the translation of address terms. Based on the level of accuracy there are three groups of data; accurate, less accurate, and inaccurate.

From 170 data, most of them have high level of accuracy. The level of accuracy of the translation of the address terms in the novel entitled "Percy Jackson \& The Olympian: The Lightning Thief" is 2.80. It can be seen that the accuracy level of the translation is high.

Table 3 The Level of Accuracy

\begin{tabular}{lll}
\hline The Level of Accuracy & Total Data & Percentage (\%) \\
\hline Accurate & 150 & $88.23 \%$ \\
Less Accurate & 7 & $4.12 \%$ \\
Not Accurate & 13 & $7.65 \%$ \\
& 170 & $100 \%$ \\
TOTAL & & \\
\hline
\end{tabular}

The high level of accuracy in this research is the result of the application of several techniques. Established equivalent technique is applied the most by the translator in this research. It is very clear that this technique makes a big contribution to the high level of accuracy of the translation of the address terms in the novel. Established equivalent is mostly applied to translate title, generic first name, mockery name, etc. Pure borrowing also contributes to the high level of accuracy of the translation. It is because the proper names, such as first name, last name, complete name, etc. will not become accurate if the translator applies other techniques. 
The application of deletion and discursive creation in the translation of the address terms is the main reason of the reduction of the accuracy level of the address terms. The application of deletion can cause a change in the message and confusion to the readers, in which without the address terms the readers can get confused about whom the speaker is talking with. The use of discursive creation also gives a huge contribution in lowering the level of the accuracy of the address terms. The use of this technique causes total change in the message in the target language. Thus, it reduces the accuracy level of the translation of address terms.

\section{b. The level of acceptability}

The definition of acceptability is that the language which the translator uses in the target text already fits the culture and the linguistic norm in the target text (Nababan et al., 2012). It means that the translation is considered natural in the target text when the readers read the translation. Based on the level of acceptability there are three groups of data; acceptable, less acceptable, and not acceptable. The majority of the data have high level of acceptability. The acceptability level of the translation of address terms in the novel entitled "Percy Jackson \& The Olympian: The Lightning Thief" is 2.9. It can be concluded that the acceptability level of the translation is high.

Table 4 The Level of Acceptability

\begin{tabular}{lll}
\hline The Level of Acceptability & Total Data & Percentage (\%) \\
\hline Acceptable & 158 & $92.94 \%$ \\
Less Acceptable & 7 & $4.12 \%$ \\
Unacceptable & 5 & $2.94 \%$ \\
TOTAL & 170 & $100 \%$ \\
\hline
\end{tabular}

The high level of acceptability of the translation is because the translator translates the address terms into translation that fit the culture and linguistic norm of the target language. The application of established equivalent technique highly contributes to the level of acceptability because some of the address terms will not become acceptable if the translator uses different techniques. Pure borrowing also contributes to the high level of the acceptability. It is because pure borrowing is used to translate proper 
names, such as first name, last name, etc. and it will confuse the reader if the address term in the form of proper names are changed.

Similar to the accuracy level, deletion and literal translation are the main reason for the reduction in the acceptability level of the translation. The use of both techniques does not fit the culture of the target text, thus making the address terms become less acceptable. 
Conclusion

There are 15 types of address terms which are found in this research. The types of address terms which are found in this novel are title, first name, generic first name, diminutive first name, last name, complete name, title plus last name, mockery name, pet name, descriptive name, kinship term, expectation name, single name, title plus single name, and title plus contraction. The translator applies 11 different techniques to translate the address terms in the novel entitled "Percy Jackson \& The Olympians: The lightning thief' The types of techniques which are found in this research are deletion, discursive creation, established equivalent, explicitation, generalization, literal, modulation, particularization, pure borrowing, addition, and reduction. The translator applied single and combination of the techniques. In this case, I found two classifications, which are single technique and combination of 2 techniques. It is found that the translator uses 9 types of single technique and 5 combinations of two techniques. The average score of the accuracy of the translation of the address terms in the novel entitled "Percy Jackson $\&$ The Olympians: The lightning thief' is 2.80 . This score indicates that the accuracy of the translation of the address terms is high. The average score of the acceptability of the translation of the address in the "Percy Jackson \& The Olympians: The lightning thief"is 2.9. This score indicates that the acceptability of the translation is high. It is found that established equivalent and pure borrowing make a big contribution to the high level of accuracy and acceptability. 


\section{REFERENCES}

Crystal, D. (2008). A dictionary of linguistics and phonetics $\left(6^{\text {th }}\right.$ ed.). USA: Blackwell Publishing.

Fauliyah, S. (2012). Translation of address term in ketika cinta bertasbih ii (Indonesian-English subtitle). Anglicist, 1(2), 29-35.

Lotfallahi, B. \& Dabbaghi, A. (2012). Translation of terms of address from English into Persian: Strategies in focus. Mediterranean journal of social sciences, 3(3), 329-333.

Molina, L. \& Albir, A. H. (2002). Translation techniques revisited: A dynamic and funtionalist. 47(4), 498-512.

Nababan, M. R. (2008). Teori menerjemah bahasa inggris. Yogyakarta. Pustaka Belajar

Nababan, M., Nuraeni, A., \& Sumardiono. (2012). Pengembangan model penilaian kualitas terjemahan.Kajian linguistik dan sastra, 24(1), 39-57. Surakarta: Universitas Sebelas Maret.

Newmark, P. (1988). A textbook of translation. New York: Prentice Hall Inc.

Wardhaugh, R. (1988). An introduction to sociolinguistics. New York: Basil Blackwell.

Widyastuti. (2015). Penerjemahan sistem tutur sapa dalam subtittling dari Bahasa Inggris ke Bahasa Indonesia. Paper presented at Seminar nasional prasasti ii: Kajian pragmatic dalam berbagai bidang.

Yang, C. (2010). Translation of English and Chinese addressing terms from the cultural aspect. Journal of Language Teaching and Research, 1(5).

Yule, G. (1996). Pragmatics. New York: Oxford University Press. USA: Blackwell Publishing. 